\title{
Phenotypic and Genotypic Detection of Virulence Factors of Staphylococcus Aureus Isolated from Meat and Meat Products
}

Eid H. M. I., Gihan M. O. Mohamed, Iman, M. M. El Borolos'

\author{
Veterinarian \\ **Department of Bacteriology, immunology Mycology- Faculty of \\ Veterinary Medicine Suez Canal University \\ ***Department of Bacteriology Animal Health Research Institute Port-Said \\ branch
}

\begin{abstract}
A total of 250 random samples of meat and meat products 50 of each meat, luncheon, burger, minced meat and sausage samples were collected from different butchers in Port-Said Governorate. All samples were subjected to bacteriological examination for isolation and identification of Staph. aureus. The results revealed that the Staph. aureus was isolated in a percentage of $55(22 \%)$. The prevalence of Staph. aureus isolates in the examined meat, luncheon, burger, minced meat and sausage samples were $14 \%$, 20\%, 30\% ,34\% and 12\%, respectively. Coagulase positive Staph. aureus (CPS) was isolated in percentage of 33(60\%) from the examined meat, luncheon, burger, minced meat and sausage samples. CPS isolates could be detected in meat, luncheon, burger, minced meat and sausage samples with a percentage of $57.15 \%$, $600 \%, 60 \%, 58.82 \%$ and $66.66 \%$, respectively. The antibiotic resistance of coagulase positive Staph. aureus using 14 antibacterial drugs by disk diffusion method were resistant to Cephalexin, Chloramphenicol, Cprofloxacin, Clindamycin, Erythromycin, Vancomycin, Trimethoprim + Sulphamethoxazole, Gentamicin and Streptomycin and found with a percentage of $87.88 \%, 84.85 \%, 75.76 \%, 72.73 \%, 72.73 \%, 69.70 \%, 63.64 \%$, $60.60 \%$ and $57.58 \%$ respectively. The conventional PCR assays were developed with specific primers for the detection of different types of virulence genes in 20 strong CPS strains as protein A in Staphyloccocus (spa), coagulase (coa), haemolysin ( $h l g$ ) and intacellular adhesion (icaA) while multiplex PCR assay were developed to detect of two types of Staphylococcal enterotoxins (sea and seb). The PCR amplification of the spa gene was 3/4, 2/4, $1 / 4,1 / 4$ and 2/4 coagulase positive Staph. aureus at 226 bp from meat, luncheon, burger, minced meat and sausage respectively,
\end{abstract}


While the all 20 confirmed coagulase positive Staph. aureus was examined for coagulase (coa) gene using specific gene were positive at 360 bp. 0/4, 2/4, 0/4, 0/4 and 2/4. Identified coagulase positive Staph. aureus isolates were amplified the diagnostic DNA band successfully at $937 \mathrm{bp}$ for $\mathrm{hlg}$ gene from meat, luncheon, burger, minced meat and sausage were $4 / 4,3 / 4,3 / 4,3 / 4$ and $2 / 4$ respectively. Amplification of the icaA gene was $4 / 4,3 / 4,3 / 4,3 / 4$ and $2 / 4$ at 1315 bp from meat, luncheon, burger, minced meat and sausage respectively. Multiplex PCR could successfully amplify the diagnostic DNA bands of 102bp and $164 \mathrm{bp}$, of genes for staphylococcal enterotoxins sea and seb, respectively. The results showed that 1/4, 1/4, 2/4, 1/4 and 0/4 isolates of Staph. aureus was positive for seb at $164 \mathrm{bp}$ from meat, luncheon, burger, minced meat and sausage respectively. While none of the samples were positive for sea. The public health hazards of this microorganism, as well as improve quality status of meat and meat products were discussed.

\section{Keywords: Coagulase positive Staph. aureus, meat and meat products, virulence genes, PCR, Public health}

\section{Introduction}

Meat and meat products have an important role in human nutrition as they are desirable foodstuffs. They are important sources for protein, fat, essential amino acids, minerals, vitamins and other nutrients essential for human (Biesalski, 2005). On the other hand, they are considered an ideal culture medium for growth of many organisms due to their high content of moisture, nitrogenous compounds of various degree of complexity, plentiful supply of minerals, accessory growth factors and some fermentable carbohydrates of a favorable $\mathrm{pH}$ as glycogen (Mohammed, 2011).

The contamination of meat and meat products with microorganisms from meat handlers, which may have carried the pathogenic microorganism during the processes of manufacturing, packing and marketing. Improper cooking, poor hygiene during production processes, refrigeration or the retail and storage of foods may lead to meat borne illness and food poisoning causing death in developing countries costing billions of dollars in medical care, medical and social costs (Fratmico et al., 2005 and FDA, 2012).

Foods that require considerable handling during preparation such as meat and meat products are frequently involved in Staphylococcal food poisoning because Staphylococci exist in air, dust, sewage, water, milk, and food or on food equipment, 
environmental surfaces, humans, and animals. Staphylococci are present in the nasal passages, throats, on the hair and skin of 50 percent or more of healthy individuals. (Scott, 2003).

Staph. aureus is the predominant species involved in staphylococcal food-poisoning outbreaks (AragonAlegro et al., 2007). Staph. aureusis gram positive, cocci, facultative anaerobic, nonsporulating bacteria in which most of them are recognized on the skin, mucous membranes of humans and animals and also as environmental contaminants (Feizi et al., 2012). Staphylococcal food poisoning is caused by the ingestion of food containing pre-formed toxins secreted by the bacteria. These are known as staphylococcal enterotoxins, the staphylococcal enterotoxins (SEs) have been classified into many different types. These enterotoxins are heatstable and resistant to the action of digestive enzymes (Brooks et al., 2000). Staph. aureus is considered as one of the most dangerous pathogenic bacteria due to the production of a variety of extracellular protein toxins such as toxic shock syndrome toxin 1 (TSST-1), exfoliative toxin (ET), coagulase, hemolysins, and at least 15 types of enterotoxins (Mehrotra and Johnson 2000).

Polymerase chain reactions (PCR) is one of the molecular biologybased detection methods commonly used for detecting the main pathogens in food samples as a method provides a promising option for the rapid identification of pathogen and it can be used as a rapid, reliable method, high sensitivity, high specificity and can improve the level of detection within few hours (Tamparapu et al., 2001). PCR methods offer a sensitive and specific detection of pathogens and can discriminate virulent bacteria thus PCR-based techniques are used increasingly in food microbiology (Olsen, 2000).

Due to the rising incidence of foodborne infections, there is an urgent need for control and/or prophylaxis for food poisoning outbreaks associated with meat and meat products. It depends greatly on the investigating of the causative agents in meat and meat products, eliminating them to ensure food safety and to protect public health from microbial contamination of food. In the current study, we evaluated the prevalence and antibiotic susceptibility profiles of coagulase positive Staph. aureus (CPS) in meat and meat products including luncheon, burger, minced meat and sausage obtained from different butchers in Port-Said Governorate and to detect the presence of some of the virulence genes (spa, coa, hlg and icaA) responsible for initiation of pathogenesis of CPS using conventional PCR while multiplex PCR for detection of classical staphylococcal enterotoxins A and 
B (sea and seb) as rapid, sensitive, powerful and accurate method.

\section{Materials and methods}

\section{1- Collection of Samples:}

A total of 250 samples of meat and meat products 50 of each meat, luncheon, burger, minced meat and sausage were collected from different butcher's shop in PortSaid Governorate for isolation and identification of coagulase positive Staph. aureus. All the collected samples were put in a sterile polyethylene bag, labeled and transferred in an ice box directly to the laboratory as soon as possible.

\section{2-Bacteriological examination:}

\section{2-1 Food homogenates} preparation and isolation of the Staph. aureus.

Twenty-five gram of each of the examined samples were taken under aseptic condition into sterile blender jar to which $225 \mathrm{ml}$ peptone saline $(0.1 \%)$ was added. Then blend the mixture at 3000 rpm for 2 minute. (ICMSF, 1978). A loopful of the food homogenates was taken and cultured onto Baird parker medium, mannitol salt agar, 5\% sheep blood agar and then onto Nutrient agar. All inoculated plates were incubated at $37^{\circ} \mathrm{C}$ for $24-48 \mathrm{~h}$ then colonies were identified (Koneman et al., (1996) and Quinn et al. (2002). Suspected colonies of $\boldsymbol{S}$. aureus were examined morphologically and biochemically according to (FDA, 2001) and microscopically according to (Ryan and Ray 2004).
2-2 characteristics:

Morphological

The smear was prepared from the isolated culture and stained with Gram's stain. The stained smear revealed Gram positive, spherical cells arranged in irregular clusters resembling to bunch of grapes according to Qunin et al. (2002).

\section{2-3 Biochemical examination:}

The biochemical tests were performed to confirm CPS using Catalase test, Coagulase test, Indole production, methyl red, Voges-Proskauer, nitrate reduction, oxidase test and D-mannitol fermentation according to Thaker et al. (2013).

3- Antibiotic susceptibility testing:

The antimicrobial susceptibility test was performed using agar disc diffusion assay as described by Clinical and Laboratory Standards Institute (NCCLS, 2004). The isolates were tested for their susceptibility to 14 different antimicrobials drugs (Himedia, India) using Kirby-bauer disk diffusion method. Antimicrobials used were Amikacin (Ak) $30 \mathrm{mcg}$; cephaloxin (CL) $30 \mathrm{mg}$; Cefaclor (CEC) $30 \mathrm{mcg}$; Chloramphenicol (C) 30 ug; Clindamycin (DA) 2 mg; Ciprofloxacin (CIP) $5 \mathrm{mcg}$; Erythromycin (E) $15 \mathrm{mcg}$; Gentamicin (CN) (10mg) ; Nalidexic acid (NA) 30 ug; Neomycin (N) $30 \mathrm{ug}$; Streptomycin (S) $10 \mathrm{mg}$; Tetracycline (TE) 30ug; Trimethoprim + Sulphamexazole $\begin{array}{lll}(\mathrm{STX}) & (1.25+23.75) & \text { and }\end{array}$ 
Vancomycin (VA) $30 \mathrm{mg}$.Pure colonies of isolated Staph. aureus. were emulsified in normal saline and turbidity was matched with 0.5 McFarland turbidity standards. Selected antimicrobial discs were placed on Mueller Hinton Agar plates seeded with bacteria. These plates were incubated at $37^{\circ} \mathrm{C}$ for 24 hours. The organisms were observed for antimicrobial sensitivity based on diameters of zones of inhibition on petri-dishes. Susceptible and resistant isolates were defined according to the criteria suggested by the NCCLS (2004).

4- Molecular examination of (CPS)

\section{1- DNA extraction:}

DNA extraction from CPS was performed using the QIAamp DNA Mini kit (Qiagen, Germany, $\mathrm{GmbH}$ ). Briefly, $200 \mu \mathrm{l}$ of the bacterial culture suspension was incubated with $10 \mu \mathrm{l}$ of proteinase $\mathrm{K}$ and $200 \mu \mathrm{l}$ of lysis buffer at $56^{\circ} \mathrm{C}$ for $10 \mathrm{~min}$. Then $200 \mu \mathrm{l}$ of $100 \%$ ethanol was added to the lysate. The bacterial culture was then washed and centrifuged following the manufacturer's recommendations. Nucleic acid was eluted with $100 \mu$ l of elution buffer provided in the kit.

\section{2- Oligonucleotide Primer} staph. aureus: Primers used were supplied from

Metabion (Germany) are listed in table (1). 4.3- PCR amplification:

Multiplex PCR of enterotoxins sea, seb, sec, and see, Primers were utilized in a $50 \mu$ r reaction containing $25 \mu \mathrm{l}$ of Emerald Amp Max PCR Master Mix (Takara, Japan), $1 \mu \mathrm{l}$ of each primer of 20 pmol concentrations, $7 \mu \mathrm{l}$ of water, and $10 \mu \mathrm{l}$ of DNA template. The reaction was performed in an applied biosystem 2720 thermal cycler.

4.4- Analysis of the PCR Products:

The products of PCR were separated by electrophoresis on $1.5 \%$ agarose gel (Applichem, Germany, $\mathrm{GmbH}$ ) in $1 \mathrm{x}$ TBE buffer at room temperature using gradients of $5 \mathrm{~V} / \mathrm{cm}$. For gel analysis, $40 \mu \mathrm{l}$ of the multiplex PCR products were loaded in each gel slot and generuler $100 \mathrm{bp}$ ladders (Qiagen, Germany, $\mathrm{GmbH}$ ) were used to determine the fragment sizes. The gel was photographed by a gel documentation system (Alpha Innotech, Biometra) and the data was analyzed through computer software. 
Table (1): Primers sequences, target genes, amplicon sizes and cycling conditions:

\begin{tabular}{|c|c|c|c|c|c|c|}
\hline Gene & $\begin{array}{c}\text { Primary } \\
\text { denaturan }\end{array}$ & $\begin{array}{c}\text { Secondary } \\
\text { denaturation }\end{array}$ & Annealing & Extension & $\begin{array}{l}\text { No. of } \\
\text { cycles }\end{array}$ & $\begin{array}{c}\text { Final } \\
\text { extensi } \\
\text { on }\end{array}$ \\
\hline $\mathrm{Coa}$ & $\begin{array}{l}94^{\circ} \mathrm{C} \\
5 \mathrm{~min} .\end{array}$ & $\begin{array}{c}94^{\circ} \mathrm{C} \\
30 \mathrm{sec} .\end{array}$ & $\begin{array}{c}55^{\circ} \mathrm{C} \\
40 \mathrm{sec} .\end{array}$ & $\begin{array}{c}72^{\circ} \mathrm{C} \\
45 \mathrm{sec} .\end{array}$ & 35 & $\begin{array}{c}72^{\circ} \mathrm{C} \\
10 \mathrm{~min} .\end{array}$ \\
\hline spa & $\begin{array}{l}94^{\circ} \mathrm{C} \\
5 \mathrm{~min} .\end{array}$ & $\begin{array}{c}94^{\circ} \mathrm{C} \\
30 \mathrm{sec} .\end{array}$ & $\begin{array}{c}55^{\circ} \mathrm{C} \\
30 \mathrm{sec} .\end{array}$ & $\begin{array}{c}72^{\circ} \mathrm{C} \\
30 \mathrm{sec} .\end{array}$ & 35 & $\begin{array}{l}72^{\circ} \mathrm{C} \\
7 \mathrm{~min} .\end{array}$ \\
\hline Sea and $s e b$ & $\begin{array}{l}94^{\circ} \mathrm{C} \\
5 \mathrm{~min} .\end{array}$ & $\begin{array}{c}94^{\circ} \mathrm{C} \\
30 \mathrm{sec} .\end{array}$ & $\begin{array}{c}50^{\circ} \mathrm{C} \\
30 \mathrm{sec} .\end{array}$ & $\begin{array}{c}72^{\circ} \mathrm{C} \\
30 \mathrm{sec} .\end{array}$ & 35 & $\begin{array}{l}72^{\circ} \mathrm{C} \\
7 \mathrm{~min} .\end{array}$ \\
\hline hlg & $\begin{array}{l}94^{\circ} \mathrm{C} \\
5 \mathrm{~min} .\end{array}$ & $\begin{array}{c}94^{\circ} \mathrm{C} \\
30 \mathrm{sec} .\end{array}$ & $\begin{array}{c}58^{\circ} \mathrm{C} \\
40 \mathrm{sec} .\end{array}$ & $\begin{array}{c}72^{\circ} \mathrm{C} \\
45 \mathrm{sec} .\end{array}$ & 35 & $\begin{array}{c}72^{\circ} \mathrm{C} \\
10 \mathrm{~min} .\end{array}$ \\
\hline$i c a A$ & $\begin{array}{l}94^{\circ} \mathrm{C} \\
5 \mathrm{~min} .\end{array}$ & $\begin{array}{c}94^{\circ} \mathrm{C} \\
30 \mathrm{sec} .\end{array}$ & $\begin{array}{c}49^{\circ} \mathrm{C} \\
40 \mathrm{sec} .\end{array}$ & $\begin{array}{c}72^{\circ} \mathrm{C} \\
1 \mathrm{~min} .\end{array}$ & 35 & $\begin{array}{c}72^{\circ} \mathrm{C} \\
12 \mathrm{~min} .\end{array}$ \\
\hline
\end{tabular}

Table (2): Oligonucleotide primers sequences.

\begin{tabular}{|c|c|c|c|}
\hline Gene & Primer Sequence & $\begin{array}{c}\text { Amplified } \\
\text { produ } \\
\text { ct }\end{array}$ & Reference \\
\hline \multirow{2}{*}{$\mathrm{Coa}$} & ATA GAG ATG CTG GTA CAG G & \multirow{2}{*}{$360 \mathrm{bp}$} & \multirow{2}{*}{$\begin{array}{c}\text { Iyer and } \\
\text { Kumosani, } \\
(2011)\end{array}$} \\
\hline & GCT TCC GAT TGT TCG ATG C & & \\
\hline \multirow[t]{2}{*}{ Spa } & $\begin{array}{c}\text { TCA ACA AAG AAC AAC AAA } \\
\text { ATG C }\end{array}$ & \multirow[t]{2}{*}{$226 \mathrm{bp}$} & \multirow{2}{*}{$\begin{array}{l}\text { Wada et } \\
\text { al., (2010) }\end{array}$} \\
\hline & GCT TTC GGT GCT TGA GAT TC & & \\
\hline \multirow{2}{*}{ Sea } & GGTTATCAATGTGCGGGTGG & \multirow{2}{*}{$102 \mathrm{bp}$} & \multirow{4}{*}{$\begin{array}{c}\text { Mehrotra } \\
\text { et al., } \\
(\mathbf{2 0 0 0})\end{array}$} \\
\hline & CGGCACTTTTTTCTCTTCGG & & \\
\hline \multirow{2}{*}{$\mathrm{Seb}$} & GTATGGTGGTGTAACTGAGC & \multirow{2}{*}{$164 \mathrm{bp}$} & \\
\hline & CCAAATAGTGACGAGTTAGG & & \\
\hline \multirow{2}{*}{$H l g$} & GCCAATCCGTTATTAGAAAATGC & \multirow{2}{*}{$937 \mathrm{bp}$} & \multirow{2}{*}{$\begin{array}{l}\text { Kumar } e t \\
\text { al., (2009) }\end{array}$} \\
\hline & CCATAGACGTAGCAACGGAT & & \\
\hline \multirow[b]{2}{*}{$i c a A$} & CCT AAC TAA CGA AAG GTA G & \multirow{2}{*}{$1315 \mathrm{bp}$} & \multirow{2}{*}{$\begin{array}{c}\text { Ciftci } e t \\
\text { al., (2009) }\end{array}$} \\
\hline & AAG ATA TAG CGA TAA GTG C & & \\
\hline
\end{tabular}




\section{Results}

Table (3): Prevalence of Staph. aureus from the examined samples of meat and meat products

\begin{tabular}{|c|c|c|c|c|c|}
\hline \multirow{2}{*}{$\begin{array}{c}\text { Types of } \\
\text { samples }\end{array}$} & $\begin{array}{c}\text { Examined } \\
\text { samples }\end{array}$ & \multicolumn{2}{|c|}{$\begin{array}{c}\text { Staph. aureus } \\
\text { positive samples }\end{array}$} & \multicolumn{2}{c|}{$\begin{array}{c}\text { Staph. aureus } \\
\text { negative samples }\end{array}$} \\
\cline { 2 - 6 } & No. & No. & $\%$ & No. & $\%$ \\
\hline Meat & 50 & 7 & 14 & 43 & 86 \\
\hline Luncheon & 50 & 10 & 20 & 40 & 80 \\
\hline Burger & 50 & 15 & 30 & 35 & 70 \\
\hline $\begin{array}{c}\text { Minced } \\
\text { meat }\end{array}$ & 50 & 17 & 34 & 33 & 66 \\
\hline Sausage & 50 & 6 & 12 & 44 & 88 \\
\hline Total & 250 & 55 & 22 & 195 & 78 \\
\hline
\end{tabular}

Table (4): Prevalence of coagulase positive and negative Staph. aureus from the examined samples of meat and meat products

\begin{tabular}{|c|c|c|c|c|c|}
\hline \multirow{2}{*}{$\begin{array}{c}\text { Types of } \\
\text { samples }\end{array}$} & $\begin{array}{l}\text { Examined } \\
\text { strain }\end{array}$ & \multicolumn{2}{|c|}{$\begin{array}{c}\text { Coagulase +ve } \\
\text { strain of } \\
\text { Staph. aureus }\end{array}$} & \multicolumn{2}{c|}{$\begin{array}{c}\text { Coagulase -ve } \\
\text { strain of } \\
\text { Staph.aureus }\end{array}$} \\
\cline { 2 - 6 } & No. & No. & \% & No. & $\%$ \\
\hline Meat & 7 & 4 & 57.15 & 3 & 42.85 \\
\hline Luncheon & 10 & 6 & 60 & 4 & 40 \\
\hline Burger & 15 & 9 & 60 & 6 & 40 \\
\hline Minced meat & 17 & 10 & 58.82 & 7 & 41.18 \\
\hline Sausage & 6 & 4 & 66.66 & 2 & 33.33 \\
\hline Total & 55 & 33 & 60 & 22 & 40 \\
\hline
\end{tabular}

Table (5): Results of coagulase $++++v e$ test of Staph. aureus from examined samples of meat and meat products

\begin{tabular}{|c|c|c|}
\hline Types of samples & $\begin{array}{c}\text { Examined } \\
\text { strain }\end{array}$ & $\begin{array}{c}\text { Coagulase ++++ve strain } \\
\text { of } \\
\text { Staph. } \text { aureus }\end{array}$ \\
\cline { 2 - 3 } & No. & No. \\
\hline Meat & 4 & 4 \\
\hline Luncheon & 6 & 4 \\
\hline Burger & 9 & 4 \\
\hline Minced meat & 10 & 4 \\
\hline Sausage & 4 & 4 \\
\hline Total & 33 & 20 \\
\hline
\end{tabular}


Table (6): Antibiotic resistance of coagulase positive Staph. aureus (33 isolates) isolated from the examined meat and meat products to different antimicrobial agents.

\begin{tabular}{|l|c|c|c|c|}
\hline \multirow{2}{*}{ Antibacterial agents } & \multicolumn{2}{|c|}{ Resistant } & \multicolumn{2}{c|}{ Sensitive } \\
\cline { 2 - 5 } & $\begin{array}{c}\text { No. of } \\
\text { strain }\end{array}$ & $\%$ & No. of strain & $\%$ \\
\hline Cephaloxin (CL) & 29 & 87.88 & 4 & 12.12 \\
\hline Chloramphenicol (C) & 28 & 84.85 & 5 & 15.15 \\
\hline Ciprofloxacin (CIP) & 25 & 75.76 & 8 & 24.24 \\
\hline Clindamycin (DA) & 24 & 72.73 & 9 & 27.27 \\
\hline Erythromycin (E) & 24 & 72.73 & 9 & 27.27 \\
\hline $\begin{array}{l}\text { Trimethoprim - } \\
\text { Sulphamethoxazole (SXT) }\end{array}$ & 21 & 63.64 & 12 & 36.36 \\
\hline Vancomycin (VA) & 23 & 69.70 & 10 & 30.30 \\
\hline Gentamicin (CN) & 20 & 60.60 & 13 & 39.40 \\
\hline Streptomycin (S) & 19 & 57.58 & 14 & 42.42 \\
\hline Amikacin (Ak) & 14 & 42.42 & 19 & 57.58 \\
\hline Neomycin (N) & 1 & 3.03 & 32 & 96.97 \\
\hline Cefaclor (CEC) & 7 & 21.21 & 26 & 78.79 \\
\hline Tetracyclin (TE) & 3 & $9.10 \%$ & 30 & 90.90 \\
\hline Nalidixic acid (NA) & 4 & $12.12 \%$ & 29 & 87.88 \\
\hline
\end{tabular}

Table (7): Distribution of the virulence genes of Staph. aureus isolated from the examined samples of meat and meat products

\begin{tabular}{|c|c|c|c|c|c|c|c|c|c|c|c|c|c|c|c|c|c|c|c|c|}
\hline \multirow{2}{*}{$\begin{array}{c}\text { Gen } \\
\text { e }\end{array}$} & \multicolumn{1}{|c|}{ Meat } & $\mathbf{2}$ & $\mathbf{3}$ & $\mathbf{4}$ & $\mathbf{5}$ & $\mathbf{6}$ & $\mathbf{7}$ & $\mathbf{8}$ & $\mathbf{9}$ & $\mathbf{1}$ & $\mathbf{1}$ & $\mathbf{1}$ & $\mathbf{1}$ & $\mathbf{1}$ & $\mathbf{1}$ & $\mathbf{1}$ & $\mathbf{1}$ & $\mathbf{1}$ & $\mathbf{1}$ & $\mathbf{2}$ \\
& & & & & & & & & & $\mathbf{0}$ & $\mathbf{1}$ & $\mathbf{2}$ & $\mathbf{3}$ & $\mathbf{4}$ & $\mathbf{5}$ & $\mathbf{6}$ & $\mathbf{7}$ & $\mathbf{8}$ & $\mathbf{9}$ & $\mathbf{0}$ \\
\hline spa & + & + & + & - & - & + & - & + & - & - & - & + & + & - & - & - & - & - & + & + \\
\hline coa & + & + & + & + & + & + & + & + & + & + & + & + & + & + & + & + & + & + & + & + \\
\hline hlg & - & - & - & - & - & + & - & + & - & - & - & - & - & - & - & - & - & - & + & + \\
\hline icaA & + & + & + & + & + & + & - & + & + & + & - & + & + & + & - & + & - & - & + & + \\
\hline Sea & - & - & - & - & - & - & - & - & - & - & - & - & - & - & - & - & - & - & - & - \\
\hline Seb & - & - & - & + & - & - & - & + & + & + & - & - & - & + & - & - & - & - & - & - \\
\hline
\end{tabular}

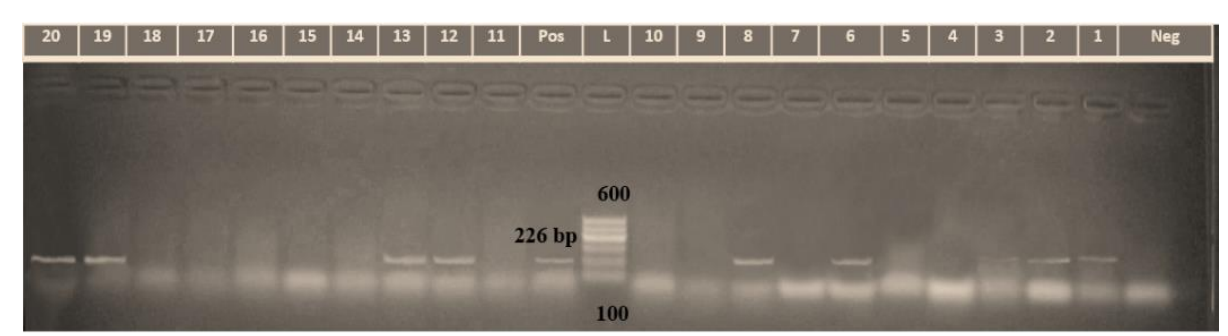

Figure 1: Agarose gel electrophoresis of PCR products after amplification of:

1- MWM-molecular weight marker (100 - 600 bp DNA ladder), + control (Positive, Negative) + different strains of $S$. aureus. 
2- spa gene (spa gene products at 226bp).

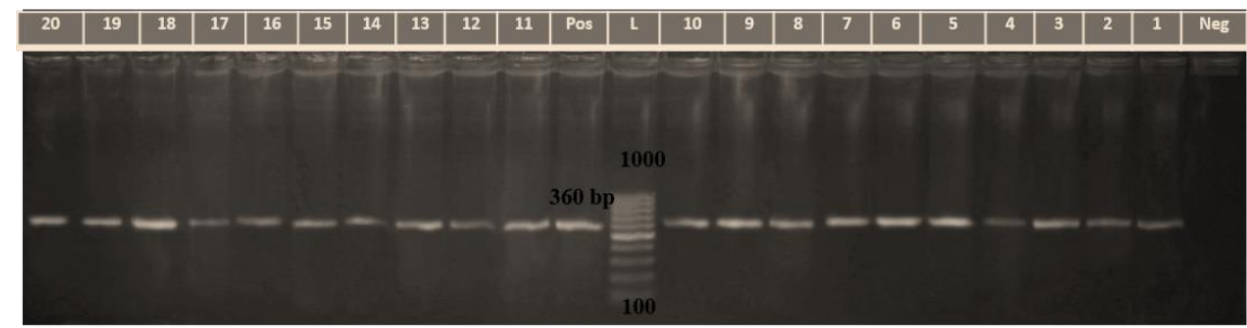

Figures (2): Agarose gel electrophoresis of PCR products after amplification of:

1- MWM-molecular weight marker (100 - 1000 bp DNA ladder), + control (Positive, Negative) + different strains of Staph. aureus.

2- coa gene (coa gene products at $360 \mathrm{bp}$ ).

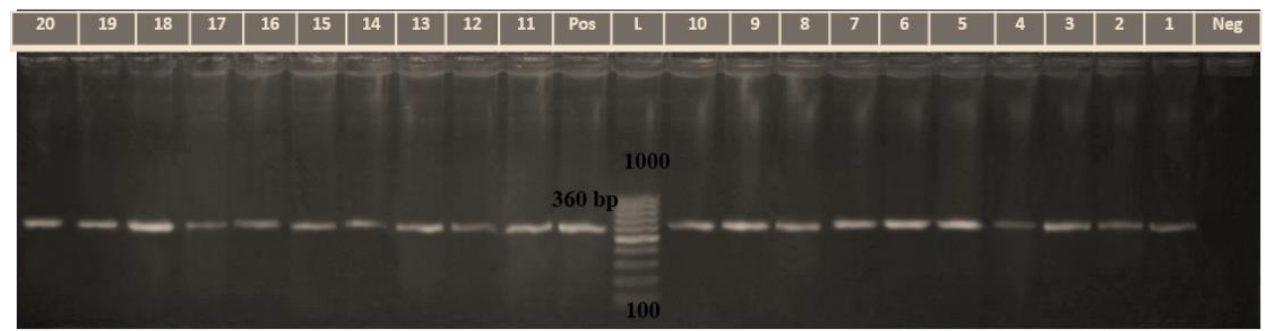

Figures (3): Agarose gel electrophoresis of PCR products after amplification of:

1- MWM-molecular weight marker (100 - 1000 bp DNA ladder), + control (Positive, Negative) + different strains of Staph. aureus. 2- hlg gene (hlg gene products at 937bp).

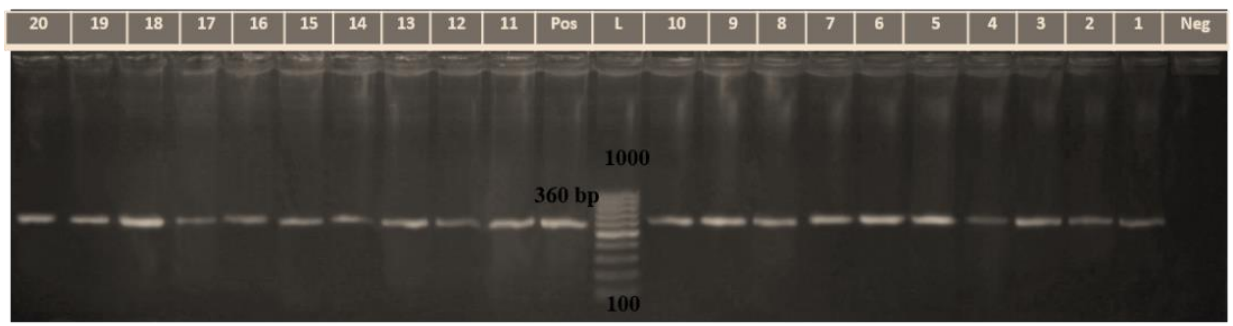

figures (4): Agarose gel electrophoresis of PCR products after amplification of:

1- MWM-molecular weight marker (100 - 1500 bp DNA ladder), + control (Positive, Negative) + different strains of Staph. aureus.

2- icaA gene (icaA gene products at $1315 \mathrm{bp}$ ). 


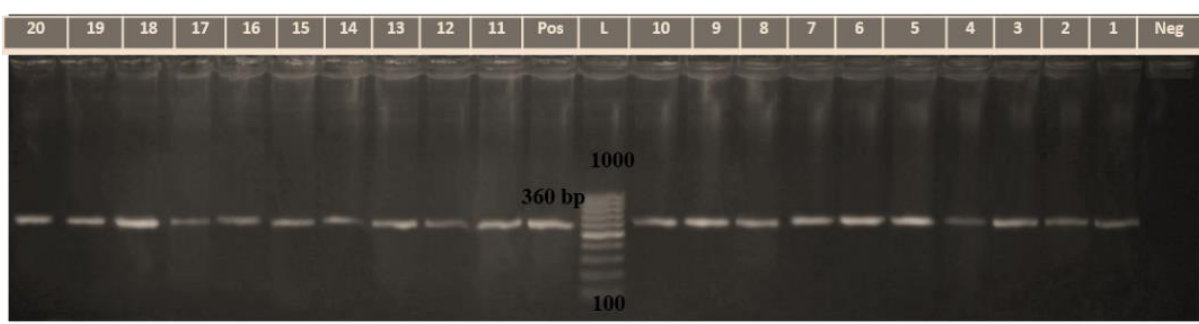

Figures (5): Agarose gel electrophoresis of PCR products after amplification of: 1- MWM-molecular weight marker $(100$ - 1500 bp DNA ladder $)$, control (Positive, Negative) + different strains of Staph. aureus.

2- sea gene (sea gene products at $102 \mathrm{bp})$. 3- seb gene (seb gene products at $164 \mathrm{bp}$

\section{Discussion}

Meat and meat products are considered the most important sources of food for people in everywhere as they supply the consumers with the required nutritive elements such as high quality proteins, essential amino acids, B-complex vitamins and certain minerals especially iron and phosphorous and beside that the meat has high calories value (Ogilvie, 2015). On the other hand meat and meat products are recognized as a major source of food borne pathogens that cause food poisoning in humans. (le Loir et al., 2003). Staph. Aureus is one of the most common causes of food-borne infections in most of the countries of the world (Bhatia and Zahoor, 2007). Coagulase positive Staph. aureus (CPS) is an important food borne pathogen and a major cause of food poisoning worldwide. Foods that require extensive handling during preparation and are kept above refrigeration temperature $\left(4^{\circ} \mathrm{C}\right)$ for extended periods after preparation are often involved in staphylococcal food poisoning (Argudín et al., 2010).

In the present study a total of 250 samples 50 of each meat, luncheon, burger, minced meat and sausage were collected from different butcher's shops in Port-Said Governorate and investigated bacteriological to detect the prevalence of Staph. aureus among the examined meat and meat products samples (Table 3). The prevalence of Staph. aureus was $55(22 \%)$. These results were more than that recorded by Gihan et al., (2015) and Gihan et al., (2016) who isolated CPS from meat and some meat products in proportion of $17.6 \%$ and $14.6 \%$ respectively. And also more than that recorded by Goja et al., (2013) and Ezzat et al., (2014) who isolated CPS from meat in proportion of $12.0 \%$ and $10 \%$, respectively. On other hand the obtained results were less than that recorded by Normanno et al., (2005); Hassan et al., (2010); Gousia et al., (2011); Hanson et al., (2011; Datta et al., (2012); 
Ezzat et al., (2014) and Fan et al., (2015) who showed lower prevalence of Staph. aureus ranged from $9.5 \%$ to $35 \%$. Another studies showed higher prevalence of Staph. aureus was obtained by Gundogan et al., (2005) and Ahmad et al., (2013) $53.3 \%$ and $51 \%$, respectively.

CPS isolates was detected in meat, luncheon, burger, minced meat and sausage samples with a percentage of $14 \%, 20 \%, 30 \%, 34 \%$ and $12 \%$, respectively as mentioned in (Table $3)$. These results were less than those reported by Watres et al., (2011) who isolated CPS from meat, sausage, Kofta, burger, meat and luncheon samples with a percentage of $64 \%, 56 \%, 52 \%$, $40 \%$ and $24 \%$, respectively. On the other hand, recoded results were less than those recorded by Azeez et al., (2016) ; Mansour and Basha (2009) ; Kanika et al., (2011) and Gihan et al., (2015) who reported that incidence of CPS in meat samples from different markets were $30.2 \%, 20 \%, 20.5 \%$ and $16 \%$ respectively. The obtained results were higher than Hamzah et al., (2010) who reported lower incidence of CPS in meat $5.53 \%$. While the results of burger samples were less than Reyad and Naser, (2016) ; Gihan et al., (2015); Zakaria, (2007); Elshrek et al., (2008) and Hassanien, (2004) who isolated CPS in a percentage of $22 \%, 24 \%, 25.0 \%$ and $27.1 \%$ and $36 \%$ respectively. While the obtained results of burger samples were higher than Abass, (2014) who isolated CPS in a percentage of $3.33 \%$. The obtained results from sausage samples were less than El-Sherbeeny, (1990); Reyad and Naser (2016); El-Khateib, (1997); Mohammed et al., (2015); Soultos et al., (2003); Azeez et al., (2016) and Abass, (2014) who reported higher incidence of CPS in sausage $43 \%, 30 \%, 29 \%, 24 \%$, $19.4 \%, 18.7 \%$ and $13.33 \%$, respectively. Also our results were more than Gihan et al., (2016) who isolated CPS from meat, meat, burger, sausage and kofta in proportion of $13.33 \%, 20 \%, 6.66 \%$ and $16.66 \%$ respectively. The difference between the obtained results and the previous studies may be attributed to the total number of samples, types of samples, sampling techniques, sources and handling of samples and types of media. The high percentage of CPS in meat and meat products is indication of poor hygiene. Also their contamination returned to unhygienic manner of processing, transportation, storage and due to the insanitary condition of the butcher and absence of the health services in butcheries.

The antibiotic resistance of Staph. aureus strains isolated from animal products such as meat, luncheon, burger, minced meat and sausage of the examined samples were shown in (Table 6). The results of antibiotic sensitivity, revealed that Staph. aureus isolates were resist to Cephaoxin (86.88\%) followed by 
Chloramphenicol

Ciprofloxacin

Clindamycin

Erythromycin trimethoprim(63.64\%), (69.70\%),Gentamycin

sulphamethoxazole Vancomycin Streptomycin $(57.58 \%)$, Amikacin (42.42\%), Cefalocor (21.21\%), Nalidixic acid (12.12\%), Tetracyclin $(9.10 \%)$ and Neomycin (3.03\%). The staphylococcal isolates from the meat and meat products were found to be resistant to many of the antibiotics tested. The obtained results come within those studies by Normanno et al. (2007) who found remarkable level of resistance to several antibiotics such as Tetracycline, Erythromycin and Trimethoprim Sulfametoxazole. Gousia et al. (2011) stated that Staph. aureus isolates from beef, pork, and lamb and goat meat was resistant to one or more antimicrobials from the classes of Penicillins (narrow and broad spectrum), Macrolides (Erythromycin), Lincosamides (clindamycin), Tetracycline and Cephalosporins (Ciprofloxacin). Sharma et al. (2011) observed that Staph. aureus strains were resistant to Nalidixic acid, Amoxycillin + Sulbactam, Cloxacillin, Erythromycin, Kanamycin and Vancomycin. On the other hand several isolates were found susceptible to the Ofloxacin, Ampicillin, Tetracycline, Oxacillin, Streptomycin, Sulphafurazole and Ciprofloxacin; Daka et al., 2012) recorded that Staph. aureus were resistant to Erythromycin. Ezzat et al. (2014) observed that Staph. aureus strains isolated in their work were resistant to Chloramphenicol (95.3\%) followed by Amoxiciilin, Cephranin, Cephalothin, Gentamycin, Amikacin, Cefaclor, Norfloxacin and Erythromycin. Our results disagree with Eid et al. (2015) who detected the highest resistance rates were against Oxytetracyclin and Trimethoprim Sulphamethazole with resistance rates of $90 \%$ and $86.7 \%$, respectively.

Conventional PCR assay were developed with specific primers for confirmation and detection of different type of virulence genes PCR assays were developed with specific primers for detection of different types of virulence genes as Protein A in Staphyloccocus (spa) ,coagulase (coa), haemolysin (hlg) and intacellular adhesion (icaA).Multiplex PCR assay were developed with specific primers for detection of different type of Staphylococcal enterotoxins (sea and $s e b$ ) as mentioned in Tables (7) and Figures (1, 2, 3, 4, and 5).

Conventional PCR assays could successfully amplify the diagnostic DNA bands for Protein A (spa) (Foster, 2005 and Algammal et al., 2013) which is a component of Staph. aureus cell wall and is covalently bound to the peptidoglycan. The PCR amplification of the spa gene $3 / 4$, 
2/4, 1/4, 1/4 and 2/4 coagulase positive Staph. aureus at $226 \mathrm{bp}$ from meat, luncheon, burger, minced meat and sausage respectively, these results varied with those obtained by (Enany et al., 2013; Mehndiratta et al., 2009 and Bekhit et al., 2010) 100\%, $94.6 \%$ and $32.4 \%$ respectively, While the all 20 confirmed coagulase positive Staph. aureus was examined for coagulase (coa) gene using specific gene were positive at $360 \mathrm{bp} .0 / 4,2 / 4,0 / 4,0 / 4$ and $2 / 4$ previously. The most important phonotypical features used in the identification of Staph. aureus its ability to produce coagulase, an enzyme that causes clotting of the blood plasma, the production of coagulase enzyme could be confirmed by the presence of coagulase gene which detected by PCR (Reinoso, 2004 and Qing et al., 2012).

Identified coagulase positive Staph. aureus isolates were amplified the diagnostic DNA band successfully at $937 \mathrm{bp}$ for $h l g$ gene from meat, luncheon, burger, minced meat and sausage respectively. The results showed that the $4 / 4,3 / 4,3 / 4,3 / 4$ and $2 / 4$ respectively. Amplification of the icaA gene $4 / 4,3 / 4,3 / 4,3 / 4$ and $2 / 4$ were positive at $1315 \mathrm{bp}$ from meat, luncheon, burger, minced meat and sausage respectively. These ( $h l g$, icaA) were chosen because they have been determined to be more common among invasive isolates.11 Amplification of the genes revealed these genes were present among the different Staph. aureus isolates Jothi et al., (2009) Multiplex PCR assays were developed with specific primers for the detection of two different enterotoxins genes (sea and seb), which may be considered a significant in food safety threat. Staph. aureus produces a variety of enterotoxins types that may contribute to its pathogenicity. These results showed that from $1 / 4$, $1 / 4,2 / 4,1 / 4$ and $0 / 4$ isolates of Staph. aureus positive for seb at 164 bp from meat, luncheon, burger, minced meat and sausage respectively. None of the samples were positive for sea in Table (7). The predominant classical SE gene varied from country to country Germany, sea, sec; (Becker et al., 2001); Japan, seb; (Omoe et al., 2005); New Zealand, seb; (Boerema, et al., 2006) Poland, sec; (Bania et al., 2006); Bulgaria, sea; (Nashev et al., 2007) and Ireland, seb; (Collery et al., 2008). The differences in toxin types depend upon the origins of staphylococcal food poisoning which differed widely among countries. This may be due to differences in the consumption and food habits in each of the countries (Bhatia and Zahoor, 2007). Also the predominant classical SE gene varied from authors to another as Marcia et al. (2009) found staphylococcal enterotoxins (sea and see) in colonial sausage, and (sed and see) genes in colonial and 
American cheese, while Nashwa et al. (2015) detected sea genes only in raw meat. So the differences in the distributions of enterotoxins types in the populations strengthen the probability that some pathogenic Staph. aureus strains may returned to the different environmental, types of examined samples and geographical distributions. From the obtained results, can conclude that $S$. aureus was isolated from different and randomly samples of animal products such as meat and some meat products as luncheon, burger, minced meat and sausage samples from different butchers in port-said city. Meat and meat Products can be a source of toxigenic $S$. aureus which could potentially be spread to community through the food and represents a potential health risk for consumers. Surfaces, equipment, disinfection of animal slaughter houses and good personal hygiene can reduce spreading of $\boldsymbol{S}$. aureus and its virulence genes.

Thus from the our results we recommended that a hygienic awareness should be applied for personnel whom involved on handling and preparing of food which included proper hand washing, careful and safe handling and through cooking and processing of raw meat and meat products and also for consumers. Hazard Analysis Critical Control Point (HACCP) procedures should be adopted during all steps of manufacture, handling and storage of meat and meat products to produce safe and high quality products. Also a good hygienic practice (GHP) during meat and meat products processing is essential to control the hazards of Staphylococcal food poisoning. Quality control and routine microbiological examination should be adopted in meat butchers shops and other food rendering outlet as restaurants with a consequent certificate of nil presence food borne bacteria.

The conventional \& Multiplex PCR assay can be used as an accurate, safe and fast technique for the detection of virulence genes of $\boldsymbol{S}$. aureus in of animal products such as meat and some meat products. Those assay can be done within few hours so it act as rapid and specific diagnostic tool used for characterization of $S$. aureus isolates.

\section{References}

Abass, M. M. S. (2014): Molecular characterization of Staphylococcus aureus isolated from meat, milk and their products. M.vsc. Thesis, (Bacteriology, Immunology and Mycology) Faculty of Veterinary Medicine. Suez Canal University.

Ahmad, M.U.D.; Sarwar, A.; Najeeb, M. I.; Nawaz, M.; Anjum, A.A.; Ali, M.A. and Mansur, N. (2013): Assessment of microbial load of raw meat at abattoirs and retail outlets. J. Animal\& Plant Science, 23(3): 745748. 
Algammal, A.M.; Enany, M.E.; Khafagy, A.A, (2013): PCR based detection of genes encoding virulence determinants in Staphylococcus aureus strains isolated from bovine milk. Arabian journal of science.Home,2: First young researchers Conference at SCU.

Aragon -Alegro, L. C., Konta, E. M., Suzuki, K., Silva, M. G., Junior, A. F., Rall, R. And Rall, V. L. M. (2007): Occurrence of coagulase-positive Staphylococcus in various food products commercialized in Botucatu, SP, Brazil and detection of toxins from food and isolated strains. Food Control. 18:630-634.

Argudín, M.; Mendoza, M.C. and Rodicio MR. (2010): Food poisoning and Staphylococcus aureus enterotoxins. Toxins (Basel),2(7).

Azeez, A. Z.; Farhan, Y. I.; Ahmed, I. J.; Fakhry, S. S.; khudiar, M. M.; Ali A. A. And Ismail, L. A. (2016): Detection of Staphylococcus aureus enterotoxins genes in food collected from local markets at Baghdad city. World J. Exp. Biosci., 4(2): 93-97.

Bania, J.; Dabrowska, A.; Korzekwa， K.; Zarczynska， A.; Bystron, J.; Chrzanowska, J. And Molenda, J. (2006): The profiles of enterotoxin genes in Staphylococcus aureus from nasal carriers. Lett. Appl. Microbiol., 42, 315-320.

Becker, K.; Keller, B.; von Eiff, C.; Bruck, M.; Lubritz, G.; Etienne, J. And Peters, G. (2001):
Enterotoxigenic potential of Staphylococcus intermedius. Appl Environ Microbiol 67(12): 55515557.

Bekhit, M.M.S.; Muharram, M.M.; Alhousiny, I.M. and Hashem, M.E.S.Y. (2010): Molecular detection of genes encoding virulence determinants in Staphylococcus aureus strains isolated from bovine mastitis. J. Appl. Sci. Res., 6(2): 121-128.

Bhatia, A and Zahoor, S (2007): Staphylococcus aureus enterotoxins: A review. Journal of Clinical and Diagnostic Research. 1:188-197.

Biesalski, H. K. (2005): Meat as a component of a healthy diet. Are there any risks or benefits if meat is avoided in the diet. Meat Science; 70: 509-524.

Boerema, J. A.; Clemens, R. And Brightwel, G. (2006): Evaluation of molecular methods to determine enterotoxigenic status and molecular genotype of bovine, ovine, human and food isolates of Staphylococcus aureus. Int. J. Food Microbiol 107: 192-201.

Brooks, G. F., J. S. Butel, and S. A. Morse( 2001) : Jawetz, Melnick, \& Adelberg's Medical Microbiology, 22nd edition, Lange Medical Books/mcgraw-Hill. C. S. S Bello, A. Qahtani. (2006): Pitfalls in the routine diagnosis of Staphylococcus aureus,. Afr J Biotech, vol. 4(1), pp. 83-86.

Ciftci A., Findik A., Onuk E.E. \& Savasan S. (2009): Detection of methicillin resistance and slime 
factor production of Staphylococcus aureus in bovine mastitis. Brazilian Journal of Microbiology. 40(2): 254261.

Collery, M.M.; Smyth, D.S.;

Twohig, J.M.; Shore, A.C.;

Coleman, D.C. and Smyth, C.J.

(2008): Molecular typing of nasal carriage isolates of Staphylococcus aureus from an Irish university student population based on toxin gene PCR, agr locus types and multiple locus, variable number tandem repeat analysis. J. Med. Microbiol.57:348-358.

Daka,

D.; Gsilassie,S. and Yihdego, D. (2012): Antibiotic resistance Staphylococcus

aureus isolated from cow's milk in the Hawassa area, South Ethiopia. Annals of Clinical Microbiology and Antimicrobials, 11:26.

Eid, S. N.; S.A. and Erfan, A.M. (2015): Multidrug Resistant Bacterial Pathogens in Eggs Collected from Backyard Chickens. Assiute Vet. Med. J. 61(144): 87103.

El-Khateib, T. (1997): Microbiological status of Egyptian salted meat and fresh sausage. Journal of Food Safety, 17(3):141150.

Elsherek, Y.M.; Madi, N.S and EIBakoush, E.A. (2008): Microbiological studies of spiced beef burgers in Tripoli city, Libyan Arab Jamahiriya. Eastern Mediterranean Health Journal,18 (6): $653+$.
El-Sherbeeny, E.A. (1990): Food poisoning microorganism in Portsaidm.V.Sc. Thesis, Zagazig Univ.

Enany, M. E., Abd El-Wanis, S. A., El-Gmmal, A. M. And AboEillil, S. A. M. I. A., (2013): Phenotypic and genotypic characterization of Methicillin resistant Staph. aureus (MRSA) isolated from broiler chickens of traditional poultry slaughter shops in Ismailia province. Journal of SCVMJ, XVIII (2): 189-199.

Ezzat, M.; Shabana, I. I.;Riad, E.M.; Sarah, M.A. (2014): Molecular characterization of Staphylococcus aureus isolated from meat, milk and their products. Department of bacteriology, Animal Health Research Institute, Port-Said branch.

Fan, Y.; Li, S.M.; Deng, B.G. and Zhao, Y.X. (2015): Prevalence and revalence analysis of multidrugresistant Staphylococcus auerus of meat, poultry and human origin. Indian J. of Animal Research, 49(1): 86-90.

Feizi, A. ; Nazeri, M. and Pilevar, A. (2012): Isolation of

Staphylococcus spp. Genera from broiler breeder flocks in East Azerbaijan Province of Iran: Prevalence and antimicrobial susceptibility. African Journal of Microbiology Research. 6 (28):5819-5823.

Food and Drug Adminstration "FDA" (2001): Food Drug Adm. Bact. Analytical manual,.Chapter 12 Staphylococcus aureus. Reginald, W. B. and Gayle A. L. 
Food and Drug Administration "FDA" (2012): Bad bug book Food borne Pathogenic Microorganisms and Natural Toxins Handbook, 2nd ed. Staphylococcus aureus.

Foster, T. (2005): Immune evasion by staphylococci. Nat. Rev. Microbiol.,3(12):948-958.

Fratmico PM, B. A., Smith JL. (2005): Foodborne Pathogens in Microbiology and Molecular Biology. Caister Academic Press,Wymondham, Norfolk, UK, pp: 273.

Gihan, M. O. Mohammed, Hanan, A. Eldahshan and Rehab, E. Dawod (2016): molecular characterization of staph. aureus and some enteric bacteria producing toxins in minced meat sold in portsaid city markets assiut vet. Med. J., 62 (151):260-269.

Gihan, M. O. Mohammed; Taghreed, A. H. and Hanan, A. E. (2015): Prevalence and antimicrobial resistance of Staphylococcus aureus isolated from meat and some meat products with detection of resistant genes using PCR. Egyptian Journal Agricultural Research, 93(4):63-79.

Goja, A.M.; Ahmed, T.A.A.; Saeed, S.A.M. and Dirar, H.A.(2013):Isolation and Identification of Staphylococcus spp. in Fresh Beef.Pakistan Journal of Nutrition 12 (2): 114-120.

Gousia, V. E.; Hercules, S.; Stamatina, L.; and Chrissanthy ,P.(2011): Antimicrobial Resistance of Major Foodborne Pathogens from
Major Meat Products. Food borne pathogens and disease 8,(1).

Gundogan, N.; Citak, S.; Yucel, N. and Devren, A. (2005): A note on the incidence and antibiotic resistance of Staphylococcus aureus isolated from meat and chicken samples. Meat Science, 69: 807-810.

Hamzah, A. M.; Abbas, M. S. And Ahmed W. A. (2010): The isolation and identification of the important pathogenic bacteria from fresh meat. The Iraq J. For Vet Med 23 (1): 4450 .

Hassan, S. M. ; Haq, A. U. ; Byrd, J. A. ; Berhow, M. A. ; Cartwright, A. L. ; Bailey, C. A.,( 2010): Haemolytic and antimicrobial activities of saponin-rich extracts from guar meal. Food Chem., 119: 600-605.

Hassanien, F. S. (2004): Bacterial Hazards Associated with Consumption of Some Meat Products. Benha Vet. Med. J., 15(2):41-54.

Hanson, B.M., Dressler, A.E.;

Harper ,A.L.; Scheibel ,R.P.

(2011): Prevalence of

Staphylococcus aureus and methicillin resistant staphylococcus aureus(MRSA)on retail meat in iowa. J Infect Public Health 2011; 4:169-174.

International Commission on Microbiological Specifications for Foods( (ICMSF) (1978): Microorganism in Foods, Their Significance and Method of Enumeration. $2^{\text {nd }} \mathrm{Ed}$, Univ. of Toronto Press. Toronto Canada 
Jothi, D.K.; Yogesh, K. N.; Abhishek, G. And Deepshikha, K. (2009): Detection of virulence genes in Staphylococcus aureus isolated from paper currency. International Journal of Infectious Diseases 13: 450-455.

LeLoir, Y., Baron, F., and Gautier, M. (2003): Staphylococcus aureus and food poisoning, Genetics and Molecular Research, vol. 2, no. 1, pp. 63-76.

Kanika, B.; Xiaogang, W.; Susan, D.; Marcus, Z.; Liziane, d.; Yifan, Z .(2011): Methicillin-resistant Staphylococcus aureus in retail meat, Detroit, Michigan, USA,Emerging infectious diseases 17,6.

Koneman , E. W. A., S. D.; Janda, W. M.; Schreckenberger, P. C. and Winn, M.D.(1996): Introduction to Diagnostic Microbiology. $6^{\text {th }}$ ed., Lippincott company, Philadelphia, USA.

Kumar JD, N. Y.; Gaur A, Khanna D (2009): Detection of virulence genes in Staphylococcus aureus isolated from paper currency. International Journal of Infectious Diseases 13: e450-e455.

Mansour, A. F. A and Basha, O. A. M. (2009): Hygienic status of imported frozen beef in Alexandria markets. Assiut Vet. J. 55 (121): 318-332.

Marcia, R. P.; Cátia, S. K.; Kelen, R. A.; Thaís, R. Z. And Ana, C. M. A. (2009): Ocurrence of Staphylococcus aureus and multiplex PCR detection of classic enterotoxin genes in cheese and meat products. Brazilian Journal of Microbiology, 40:145-148.

Mehrotra, M. W., G. And, Johnson, W.M. (2000):Multiplex PCR for Detection of Genes for Staphylococcus aureus Enterotoxins, Exfoliative Toxins, Toxic Shock Syndrome Toxin 1, and Methicillin Resistance.JOURNAL OF CLINICAL MICROBIOLOGY. Vol. 38, No. 3.

Mehndiratta, P.; Bhalla, P.; Ahmed, A. And Sharma, Y. (2009): Molecular typing of methicillin resistant Staphylococcus aureus strains by PCR-RFLP of SPA gene: a reference laboratory perspective, Indian Journal of Medical Microbiology, 27(2):116122.

Mohammed, G. M. O. H., T. A. and Eldahshan, H. A. (2015): Prevalence and antimicrobial resistance of Staphylococcus aureus isolated from meat and some meat products with detection of resistant genes using PCR. Egyptian Journal Agricultural Research, 93(4):63-79.

Mohammed, F. A.(2011): The Incidence of Enterobacteriaceae Causing Food Poisoning in Some Meat Products. Adv.J. Food Sci.Technol., 3(2): 116-121.

National Committee for Clinical Laboratory Standards (NCCLS) (2004): Performance Standards for Antimicrobial Disk and Dilution Susceptibility Tests for Bacteria Isolated from Animals; $2^{\text {nd }}$ ed., NCCLS M100-S14. Clinical Laboratory Standards Institute (formerly NCCLS), Wayne, PA. 
Nashev, D.; Toshkova, K.; Bizeva, L.; Akineden, O.; La mmler, C. And Zschock, M. (2007): Distribution of enterotoxin genes among carriage-and infectionassociated isolates of Staphylococcus aureus. Lett. Appl. Microbiol., 45: 681-685.

Nashwa, O. K.; Fatma, I. E.; Hanan, A. F. And Barakat, A. M.A. (2015): Epidemiologicl and genetic studies of enterotoxigenic Staphylococcus aureus isolated from goat and human. American Journal of Infectious Diseases and Microbiology, 3, (1): 32-37.

Normanno G, Firinu A, Virgilio S, Mula G, Dambrosio A, Poggiu A, Decastelli L, Mioni R, Scuota S, Bolzoni G, Di Giannatale E, Salinetti AP, La Salandra G, Batoli M, Zuccon F, Pirino T, Sias S, Parisi A, Quaglia NC, Celano GV.(2005):Coagulase-positive staphylococci and Staphylococcus aureus in food products marketed in Italy. Int J Food Microbiol.,98 :7379.

Normanno, G.; Corrente. M.; La Salandra, G.; Dambrosio, A.; Quaglia, N.C.; Parisi, A.; Greco, G.; Bellacicco, A.L.; Virgilio, S. and Celano, G.V. (2007): Methicillin-resistant

Staphylococcus aureus (Mrsa) in foods of animal origin product in Italy. International Journal of Food Microbiology, 117: 219-222.

Ogilvie, A. (2015): beef 2015Beyond. Cattle Council of Australia National Strategies for Australia's Grass fed Beef Sector. For more information

visit www.cattlecouncil.com.au.

Olsen, J. E. (2000): DNA-based methods for detection of food-borne bacterial pathogens. Food research international. 33 (3-4):257-266.

Omoe, K., Imanishi, K. And Hu, D. L., (2005): Characterization of novel staphylococcal enterotoxinlike toxin type P. Infect Immun 73: 5540-5546.

Qing,W.U.; MD, Yan Li, M.D.; Huixia,H.u.; MS, Ming Wang, M.D., Zegang, Wu.MS.and wanzhouxu, M.S. (2012): Rapid Identification of Staph. aureus: FISH Versus PCR Methods. Lab Medicine 43( 6) 276-280.

Quinn, P. J.; B.K. Markey, M.E.; Carter, W.J.; Donnelly, F.C. ;Leonard and D. Maguire,. (2002): Veterinary Microbiology and Microbial Disease. 1st Published, Oxford: Blackwell Science Ltd.

Reinoso, E.B. (2004): Análisis epidemiológicoy molecular de cepas de Staphylococcus aureus de distintosorígenes. Tese de Doutorado, Instituto de Microbiologia, Universidad Nacional de Rio Cuarto, Argentina. 199p.

Reyad R. Shawish and Naser A. Al-Humam (2016) Contamination of beef products with staphylococcal classical enterotoxins in Egypt and Saudi Arabia. GMS Hyg Infect Control. 11.

Ryan, K. J. and Ray C.G. (2004): Sherris Medical Microbiology $4^{\text {th }}$ ed. McGraw Hill. ISBN 0-8385-8529-9. 
Scott, E. (2003): Food safety and food-borne diseases in 21st century homes. Can. J. Infect. Dis., 14: 277280.

Sharma, D. S., P.K. and Malik, A. (2011): Prevalence and antimicrobial susceptibility of drug resistant Staphylococcus aureus in raw milk of dairy cattle. . Journal of Microbiology 2(11): 466-470.

Soultos, N.; Abrahim, A. andAbrosiadis, I. (2003): Incidence of some food born bacterial pathogens in traditional sausages produced in Northen Greece. Archiv fur. Lebensmittelhygiene, 54(3):5557.

Tamarapu, S., J. L. ;mckillip and M. Drake,(2001): Development of multiplex polymerase chain reaction assay for detection and differentiation of Staphylococcus aureus in dairy products. J.Food Prot., 64: 664-668.

Thaker, H. C.; Brahmbhatt, M.N.; and Nayak, J.B. (2013): Isolation and identification of Staphylococcus aureus from milk and milk products and their drug resistance patterns in Anand, . Gujarat. Vet. World, 6 (1): 10-13.

Wada, M. L., E. ; Bian, L. ; Wang, C. ; Chiba, Y. ; Nagata, S. ; Shimizu, T. ; Yamashiro, Y. ; Asahara, T. and Nomoto, $K$. (2010): Quantitative reverse transcription-PCR assay for the rapid detection of methicillin-resistant Staphylococcus aureus. Journal of Applied Microbiology .108 : 779788.

Waters, A. E. C.C., T. ; Buchhagen, J. ; Liu, C.M. ; Watson, L. ; Pearce, K. ; Foster, J. T. ; Bowers, J. ;Driebe, E. M. ; Engelthaler, D.M. ; Keim, P.S. and Lance, B.P. (2011): MultidrugResistant Staphylococcus aureus in US Meat and Poultry. Clinical Infectious Disease, 52(10):1227-30.

Zakaria, H. H. (2007): Studies on food poisoning microorganisms in some meat products. The Degree of M. V. Sc.(Meat Hygiene \& control) .Menoufia University, Faculty of Vet. Med., Sadat branch. 


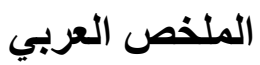

الفحص الظاهري و الجيني لعوامل الضراوة في ميكروب المكور العنقودي الأهبي

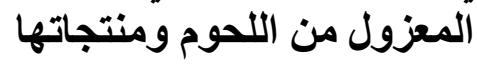

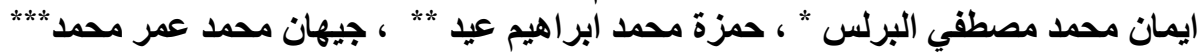

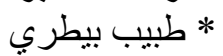

** قسم البكتريولوجي و المناعة و الفطريات ـ كلية الطب البيطري- جامعة قناة السويس

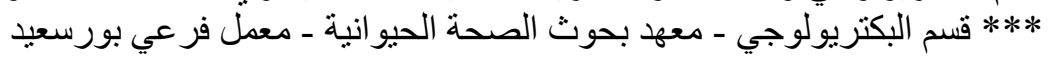

تم جمع 250 من عينات اللحوم و بعض منتجاتها (اللانشون ، البرجر ، اللحم المفروم و السجق)

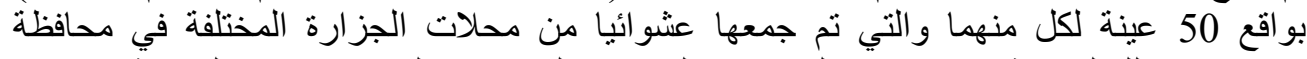

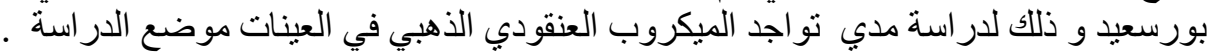

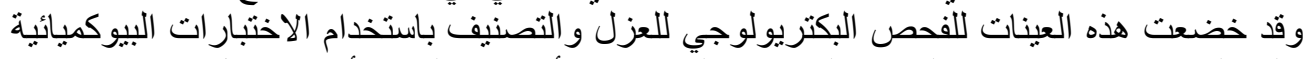

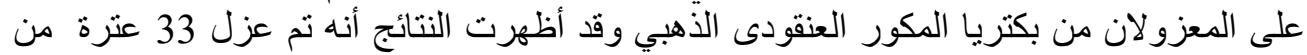

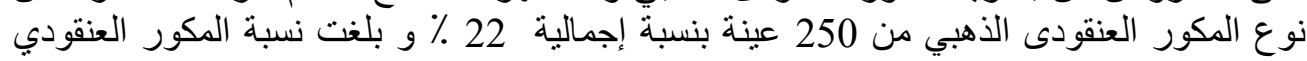

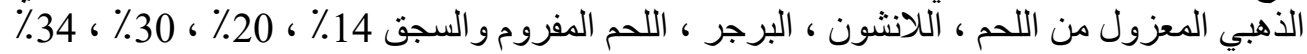

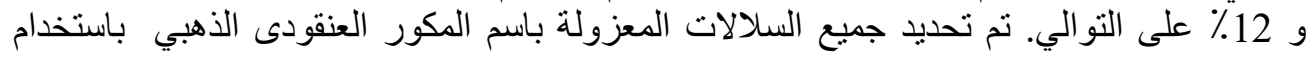

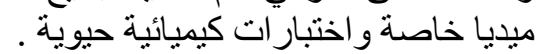

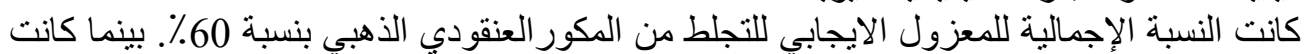

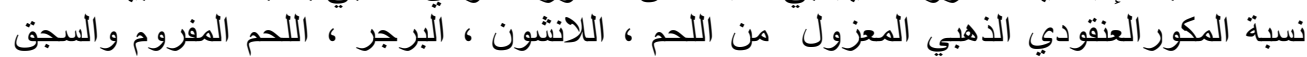

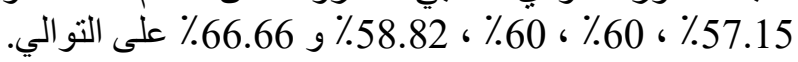

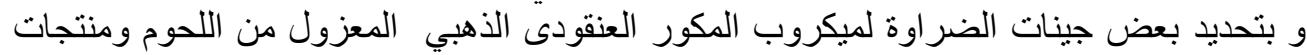

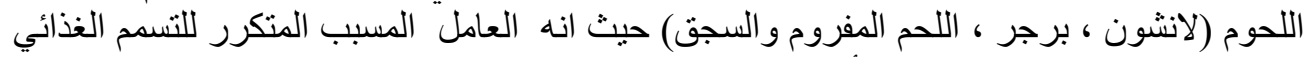

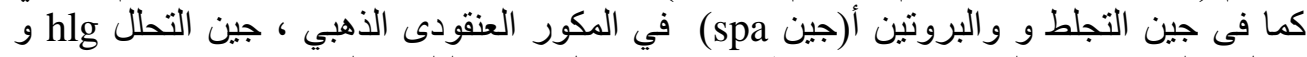

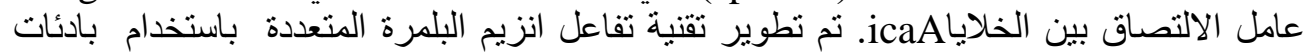

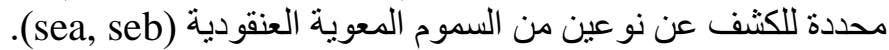

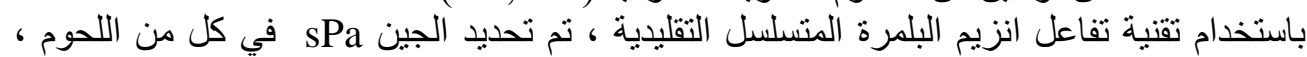

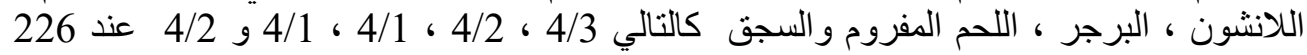

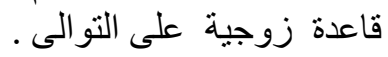

